\title{
Experimental retinal branch vein occlusion in rhesus monkeys. III. Histopathological and electron microscopical studies
}

\author{
D. J. HOCKLEY, R. C. TRIPATHI, AND NORMAN ASHTON \\ From the Department of Pathology, Institute of Ophthalmology, University of London
}

\begin{abstract}
SUMMARY Experimental retinal vein occlusion in monkeys was followed by an immediate increase in capillary permeability which was accompanied by retinal oedema. This functional capillary change was followed at about 6 hours after occlusion by structural damage to the capillary wall. Thrombus formation occurred in the damaged vessels, and areas of stasis were thus produced with associated retinal haemorrhages. Finally, there was complete loss of the capillary endothelium and pericytes, and the acellular capillaries were invaded by proliferating glial cell processes, so producing permanent capillary closure.
\end{abstract}

The clinical and fluorescein angiographic picture of experimental retinal branch vein occlusion in monkeys has been described in the preceding communication (Hamilton, et al., 1979). Selected retinae of some of the same monkeys have also been examined histologically and by electron microscopy, and in this communication we present the corresponding microscopical observations on the early stages and progression of the disease. In particular, observations have been made on the alterations which occur in the capillaries as a result of vein occlusion. Thus histological and ultrastructural explanations are provided for the clinical condition of delayed perfusion and a sequence of changes leading to irreversible capillary closure is described.

\section{Materials and methods}

Branch or hemisphere retinal veins of adult rhesus monkeys were occluded with an argon laser at a site close to the optic disc. Details of the technique have been described in the preceding communication (Hamilton et al., 1979). In nonsurvival experiments both eyes of a monkey were utilised and the animal was kept under anaesthesia for the whole period of the acute occlusion in the second eye. The eyes were enucleated from anaesthetised monkeys at the end of the selected duration of occlusion (Table 1).

HISTOLOGY AND ELECTRON MICROSCOPY Immediately after enucleation a small cut was made

Address for reprints: Professor N. Ashton, FRS, Royal College of Surgeons, Lincoln's Inn Fields, London WC2A 3PN with a razor blade at the ora serrata of the eye. The cut was enlarged with scissors to about a quarter of the eye's circumference and the eye was quickly placed in fixative. Most of the eyes were fixed initially in $3 \%$ glutaraldehyde in $0.1 \mathrm{M}$ sodium cacodylate buffer $\mathrm{pH} 7 \cdot 4$, containing $1 \mathrm{mg} / \mathrm{ml}$ of calcium chloride. The eyes were fixed for 18 hours in glutaraldehyde; fixation commenced at room temperature but continued at $4^{\circ} \mathrm{C}$ after a few hours. At the end of fixation the anterior segment was removed completely and the retina and posterior part of the eye were rinsed in cacodylate buffer containing calcium chloride and $75 \mathrm{mg} / \mathrm{ml}$ of sucrose. At this stage the fundus was examined macroscopically in conjunction with fluorescein angiographs, and pieces of the retina and choroid approximately $2 \times 4 \mathrm{~mm}$ in size were removed for further processing.

The pieces of retina, which usually displayed vascular leakage or capillary closure, were taken mainly from the area between the site of occlusion and the macula and from the area temporal to the macula; a few specimens were taken from an area nasal to the occlusion. A control, unaffected part of the retina was selected from the opposite side of the macula to the occlusion. The actual site of the occlusion was examined in some eyes (Nos. 2, 7, $11,15,16$, and 22).

The specimens were postfixed for 3 hours at $4{ }^{\circ} \mathrm{C}$ in $1 \%$ osmium tetroxide in either $0.14 \mathrm{M}$ veronal acetate buffer or $0.1 \mathrm{M}$ s-collidine buffer, $\mathrm{pH} 7 \cdot 4$. Specimens from a few monkeys were fixed only in osmium tetroxide (Table 1) and some of the specimens received a final fixation of 1.5 hours at $4^{\circ} \mathrm{C}$ in an $0.5 \%$ aqueous solution of uranyl acetate 
Table 1 Monkey retinae examined by light and electron microscopy after retinal branch vein occlusion

\begin{tabular}{|c|c|c|c|c|c|}
\hline $\begin{array}{l}\text { Eye } \\
\text { number* }\end{array}$ & $\begin{array}{l}\text { Occluded } \\
\text { vein }\end{array}$ & $\begin{array}{l}\text { Duration of } \\
\text { occlusion }\end{array}$ & $\begin{array}{l}\text { Summary of clinical and macroscopical } \\
\text { observations }\end{array}$ & $\begin{array}{l}\text { Vascular perfusion } \\
\text { tracers }\end{array}$ & Fixation \\
\hline 1 & $\begin{array}{l}\text { Right superior } \\
\text { temporal branch }\end{array}$ & $1 \mathrm{~h} 15 \mathrm{~min}$ & Slight oedema. Deep haemorrhages & - & $\begin{array}{l}\text { GA OsO } \\
\text { FS for digest }\end{array}$ \\
\hline 2 & $\begin{array}{l}\text { Left superior } \\
\text { hemisphere }\end{array}$ & $1 \mathrm{~h} 30 \mathrm{~min}$ & $\begin{array}{l}\text { Pronounced oedema. Dilatation of capillaries and } \\
\text { terminal venules with leakage. Small haemorrhages } \\
\text { superior to macula. No closure }\end{array}$ & Peroxidase & $\mathrm{GA} \mathrm{OsO}_{4}$ \\
\hline 3 & $\begin{array}{l}\text { Right inferior } \\
\text { hemisphere }\end{array}$ & $2 \mathrm{~h}$ & $\begin{array}{l}\text { Pronounced oedema. Dilatation of capillaries and } \\
\text { terminal venules with leakage. No haemorrhages. } \\
\text { Delayed filling of affected retina. Early capillary } \\
\text { collaterals temporal to macula }\end{array}$ & - & $\begin{array}{l}\mathrm{OsO}_{4} \\
\mathrm{FS} \text { for digest }\end{array}$ \\
\hline 6 & $\begin{array}{l}\text { Right inferior } \\
\text { hemisphere }\end{array}$ & $2 \mathrm{~h}$ & $\begin{array}{l}\text { Pronounced oedema. Dilatation of capillaries and } \\
\text { terminal venules with leakage. Few small } \\
\text { superficia! haemorrhages. No closure }\end{array}$ & Colloidal carbon & FS for digest \\
\hline 7 & $\begin{array}{l}\text { Right inferior } \\
\text { hemisphere }\end{array}$ & $2 \mathrm{~h} 30 \mathrm{~min}$ & $\begin{array}{l}\text { Pronounced oedema. Dilatation of capillaries and } \\
\text { terminal venules with leakage. No haemorrhages. } \\
\text { No closure }\end{array}$ & $\begin{array}{l}\text { Colloidal iron } \\
\text { and colloidal } \\
\text { carbon }\end{array}$ & GA OsO, UA \\
\hline 11 & $\begin{array}{l}\text { Left inferior } \\
\text { hemisphere }\end{array}$ & $3 \mathrm{~h} 30 \mathrm{~min}$ & Some oedema. No fluorescein photographs & Peroxidase & $\mathrm{GA} \mathrm{OsO}_{4}$ \\
\hline 13 & $\begin{array}{l}\text { Left inferior } \\
\text { hemisphere }\end{array}$ & $4 \mathrm{~h}$ & $\begin{array}{l}\text { Some oedema. Small haemorrhages inferior to } \\
\text { macula. No fluorescein photographs }\end{array}$ & Peroxidase & $\mathrm{GA} \mathrm{OsO}_{4}$ \\
\hline 14 & $\begin{array}{l}\text { Right inferior } \\
\text { hemisphere }\end{array}$ & $5 \mathrm{~h} 30 \mathrm{~min}$ & $\begin{array}{l}\text { Some oedema. Dilatation of capillaries and terminal } \\
\text { venules with extensive leakage. Few superficial } \\
\text { haemorrhages. Delayed filling of affected retina. } \\
\text { Small area of capillary nonperfusion }\end{array}$ & - & $\mathrm{GA} \mathrm{OsO}_{4} \mathrm{UA}$ \\
\hline 15 & $\begin{array}{l}\text { Right superior } \\
\text { hemisphere }\end{array}$ & $7 \mathrm{~h}$ & $\begin{array}{l}\text { Some oedema. Few superficial haemorrhages. No } \\
\text { fluorescein photographs }\end{array}$ & Colloidal iron & $\mathrm{GA} \mathrm{OsO}_{4} \mathrm{UA}$ \\
\hline 16 & $\begin{array}{l}\text { Left inferior } \\
\text { hemisphere }\end{array}$ & $24 \mathrm{~h}$ & $\begin{array}{l}\text { Some oedema. Dilatation of capillaries and terminal } \\
\text { venules with leakage. Few scattered haemorrhages. } \\
\text { Some small areas of capillary nonperfusion }\end{array}$ & - & $\begin{array}{l}\mathrm{OsO}_{4} \\
\mathrm{FS} \text { for digest }\end{array}$ \\
\hline 22 & $\begin{array}{l}\text { Left inferior } \\
\text { hemisphere }\end{array}$ & 7 days & $\begin{array}{l}\text { Some oedema. Dilatation of capillaries and terminal } \\
\text { venules with leakage. Extensive haemorrhages. } \\
\text { Capillary closure }\end{array}$ & $\begin{array}{l}\text { Colloidal iron } \\
\text { and colloidal } \\
\text { carbon }\end{array}$ & $\mathrm{GA} \mathrm{OsO}_{4} \mathrm{UA}$ \\
\hline 32 & $\begin{array}{l}\text { Left inferior } \\
\text { hemisphere }\end{array}$ & 14 days & $\begin{array}{l}\text { No oedema. Capillary and terminal venular leakage. } \\
\text { Extensive haemorrhages and cotton-wool spots } \\
\text { adjacent to occlusion. Large areas of peripheral } \\
\text { capillary nonperfusion }\end{array}$ & Colloidal carbon & FS for digest \\
\hline 33 & $\begin{array}{l}\text { Right inferior } \\
\text { hemisphere }\end{array}$ & 14 days & $\begin{array}{l}\text { No oedema. Extensive deep haemorrhages. Capillary } \\
\text { nonperfusion. Veins appear as white lines. Large } \\
\text { collaterals temporal to macula }\end{array}$ & Peroxidase & $\mathrm{GA} \mathrm{OsO}_{4} \mathrm{UA}$ \\
\hline 41 & $\begin{array}{l}\text { Left inferior } \\
\text { hemisphere }\end{array}$ & 35 days & $\begin{array}{l}\text { No oedema. Haemorrhages. Capillary closure. } \\
\text { Venous and arterial narrowing and sheathing }\end{array}$ & - & $\begin{array}{l}\mathrm{OsO}_{4} \\
\text { FS for digest }\end{array}$ \\
\hline
\end{tabular}

*Eye numbers are the same as those used in preceding communication. $\mathbf{G A}=$ Glutaraldehyde. OsO $_{4}=\mathrm{Osmium}$ tetroxide. $\mathrm{UA}=\mathrm{Uranyl}$ acetate. FS = Formol saline

adjusted to $\mathrm{pH} 5$ and containing $45 \mathrm{mg} / \mathrm{ml}$ of sucrose (Table 1). All specimens were dehydrated in ethanol and embedded in Araldite. Thick and thin sections were cut with glass knives and a LKB ultramicrotome. Thick sections were stained with toluidine blue for light microscopy; thin sections were stained with alcoholic uranyl acetate and lead citrate and examined with a JEM 100C electron microscope.

\section{TRACER PERFUSION}

The retinal blood vessels of some eyes were examined by light microscopy after perfusion of the monkeys with (a) colloidal carbon or by electron microscopy after perfusion with $(b)$ colloidal iron, or (c) horseradish peroxidase (Table 1).

(a) Approximately $100 \mathrm{ml}$ of colloidal carbon (Indian ink: Kandadar) was injected through a wide-bore needle into the left ventricle of the heart 
5 minutes before the eye was enucleated. The eye was fixed in formol saline and the retina was examined first as a flat preparation and subsequently as a digest preparation. The retina was separated from the choroid before it was mounted, and the pigment epithelium was removed by gentle brushing. The choroid of 1 eye (No. 6) was also examined as a flat preparation.

(b) $5 \mathrm{ml}$ of saccharated colloidal iron (Evans), equivalent to $100 \mathrm{mg}$ iron, was injected into the carotid artery 5 minutes before the eye was enucleated and processed in the normal way for electron microscopy.

(c) $1 \mathrm{~g}$ of crude horseradish peroxidase (Sigma) in $5 \mathrm{ml}$ of saline was injected into the femoral vein 15 minutes before the eye was enucleated. After glutaraldehyde fixation the specimens were cut into slices approximately $100 \mu \mathrm{m}$ in thickness and incubated in $3 \cdot 3^{\prime}$-diaminobenzidine tetrahydrochloride according to the method of Graham and Karnovsky (1966). The specimens were then treated according to the normal schedule but without uranyl acetate fixation.

\section{DIGEST PREPARATIONS}

Retinae or parts of retinae of some monkeys (Table 1) were digested by the technique of Ashton (1963). The preparations were stained with haematoxylin and eosin.

\section{Results}

The observations on individual eyes are grouped into 3 postocclusion time periods: 1 to 4 hours, 5 to 24 hours, and 7 to 35 days. For each of these periods 3 aspects of the eye are described: (a) the appearance of the vein and adjacent retina and choroid at the site of occlusion; (b) the changes in the retinal microvasculature in the territory of the occluded vein; (c) changes in the nonvascular or neural cells of the retina and associated tissues, again in the area drained by the occluded vein.

\section{TO 4 HOURS AFTER OCCLUSION}

(a) Site of occlusion (eyes 2, 7, 11)

Examination of the actual site of the laser burn revealed that the occluded vein was filled with erythrocytes, platelets, and fibrin. The vessel was distended by its contents and the endothelium was totally degenerate and absent in many places. The muscle cells of the vessel wall were also necrotic but the basement membranes were present so that there were no complete breaks or gaps in the wall. The inner retinal layers were highly degenerate within a distance of approximately $500 \mu \mathrm{m}(0.5 \mathrm{~mm})$ from the vein, and the outer layers and choriocapillaries were damaged over a slightly greater area. However, beyond a distance of approximately $1 \mathrm{~mm}$ from the vein occlusion the retina appeared to be normal. The neighbouring artery also appeared to be undamaged by the vein occlusion.

(b) Retinal vascular changes (eyes 1, 2, 3, 6, 7, 11, 13) Many of the capillaries in the territory of the occluded vein appeared to be completely normal at these early times and no abnormalities were detected in digest preparations. A flat preparation of the retina from the eye (No. 6) which had been perfused with carbon showed engorgement of the occluded vein, and there was also more prominent filling of the obstructed parts of the capillary bed than in the unaffected areas.

Sections of dilated venules showed their thin or flattened endothelial cells with spindle-shaped nuclei. No damage or breaks in the endothelium were detected, and apart from the change in shape the cells appeared normal. Dilated capillaries with a wide lumen and a thin endothelium (Fig. 1) were present in the sections, but the same specimens also contained capillaries with a shrunken or compressed appearance (Fig. 2). The latter vessels were often adjacent to small areas of severe retinal oedema. The cross-sectional shape of the flattened vessels was irregular and the endothelial cell nuclei were indented and folded, but the most abnormal feature was the slit-like state of the lumen (Fig. 2). The cytoplasm of the endothelium was slightly more electron-dense than normal, and at later times the mitochondria were swollen. Similar, and occasionally more marked cytoplasmic changes were seen in the pericytes.

Although no morphological site of leakage was identified, all the specimens had a few erythrocytes outside the blood vessels. The extravascular blood cells were situated between the neural cells, and they were adjacent to capillaries which were entirely normal. The flat preparation of carbon perfused vessels revealed one small area of carbon leakage in the obstructed microvasculature temporal to the macula. Leakage was best demonstrated in a specimen (No. 2) perfused with peroxidase. The electron-dense peroxidase reaction product was visible in the lumens of all the capillaries (Fig. 3a), including those with a slit-like lumen. Peroxidase was also found in small extracellular spaces adjacent to some capillaries and larger amounts of extracellular peroxidase were present in the outer plexiform layer (Fig. $3 a$ ). The basement membrane of the capillaries often contained peroxidase, and there were vacuoles and smaller pinocytotic vesicles containing peroxidase in the endothelial cells. These vesicles were seen opening both to the lumen and to the basement 


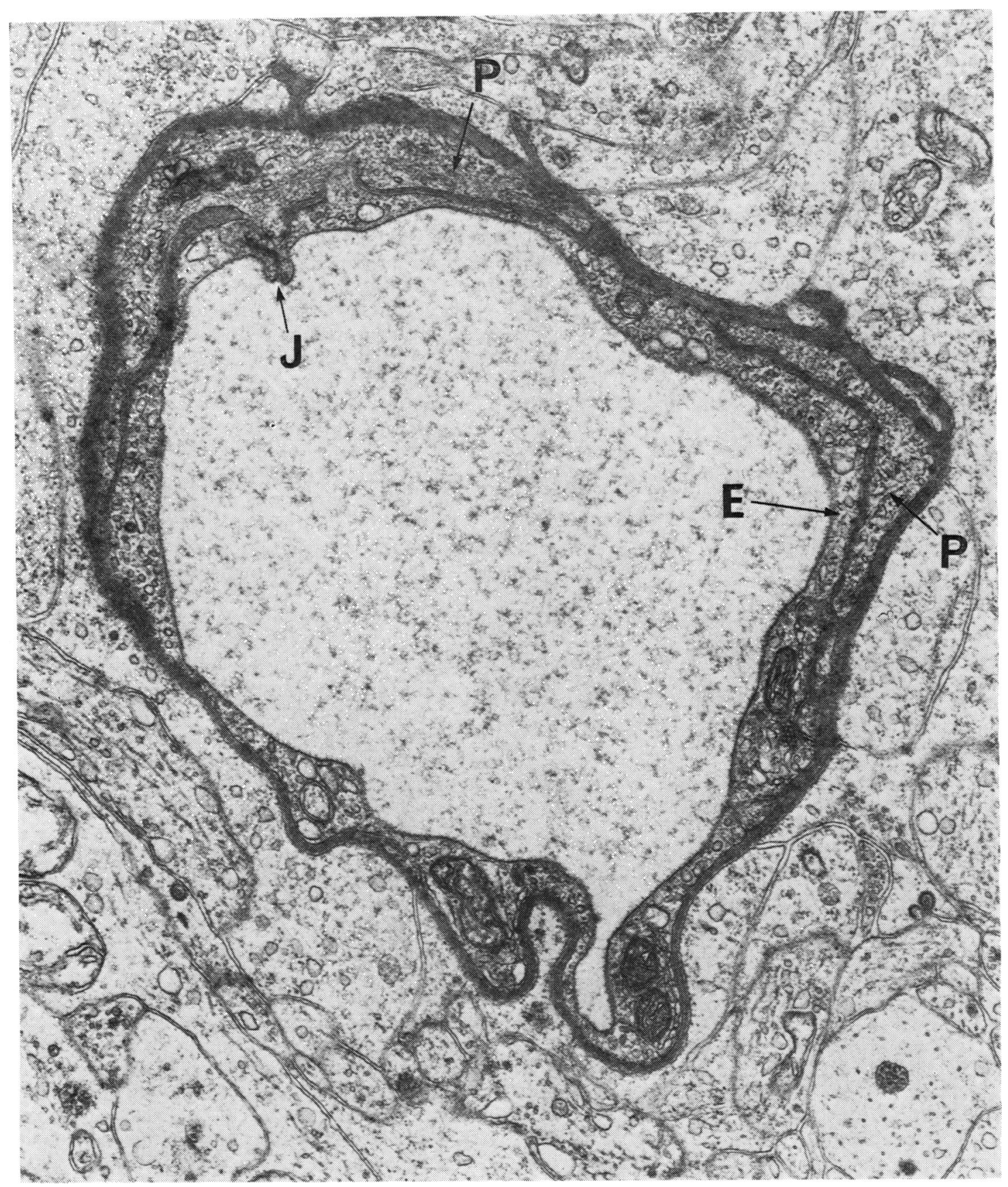

Fig. 1 Electron micrograph of a dilated capillary $2 \mathrm{~h}$ after occlusion. The endothelium $(E)$, pericytes $(P)$, and the intercellular junction $(J)$ all appear to be undamaged $(\times 24000)$ 


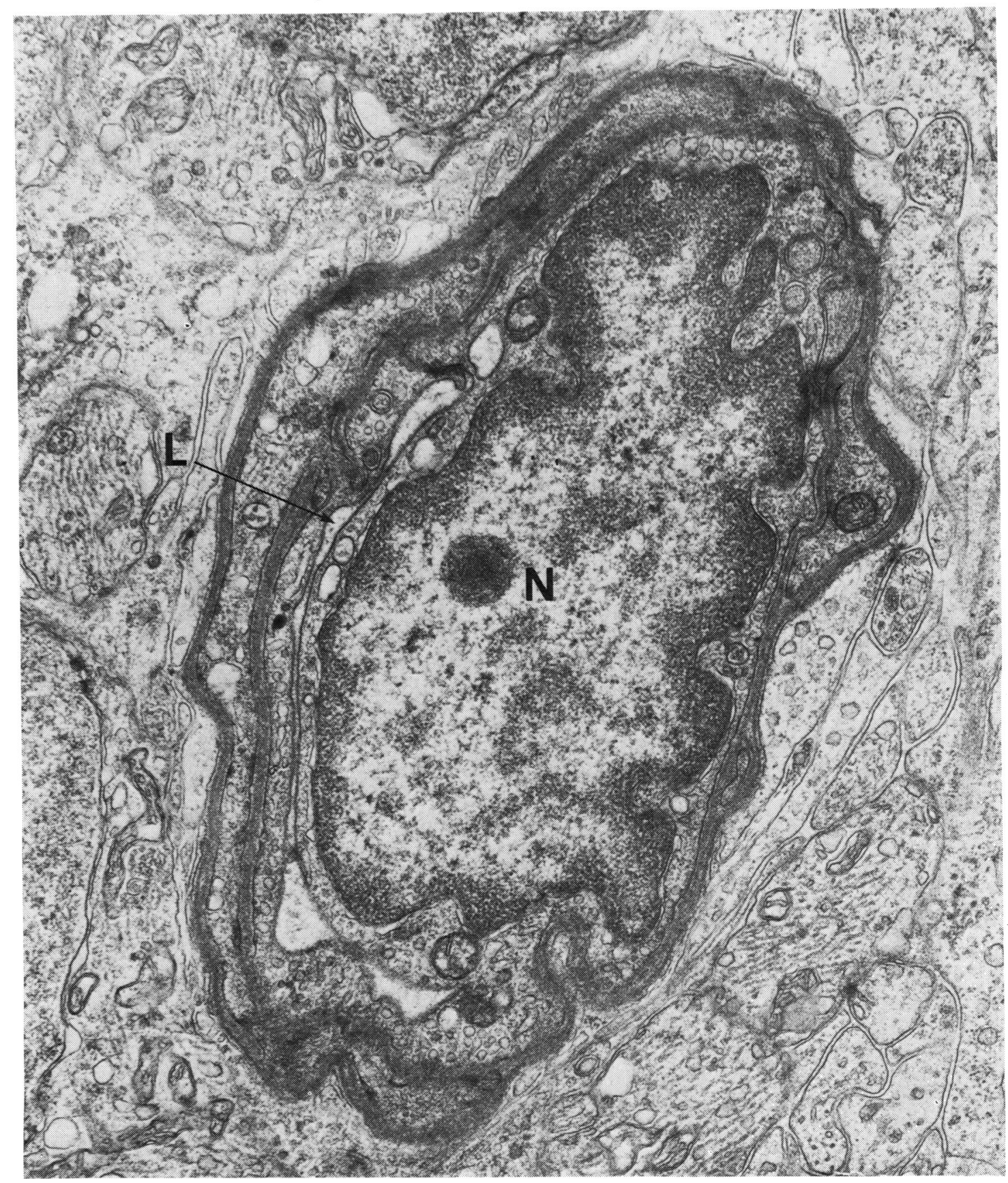

Fig. 2 Capillary with a thin and flattened lumen (L) $2 \mathrm{~h}$ after occulsion. The endothelial nucleus (N) has an irregular and indented outline but otherwise the cells appear to be normal. Electron micrograph $(\times 24000)$ 

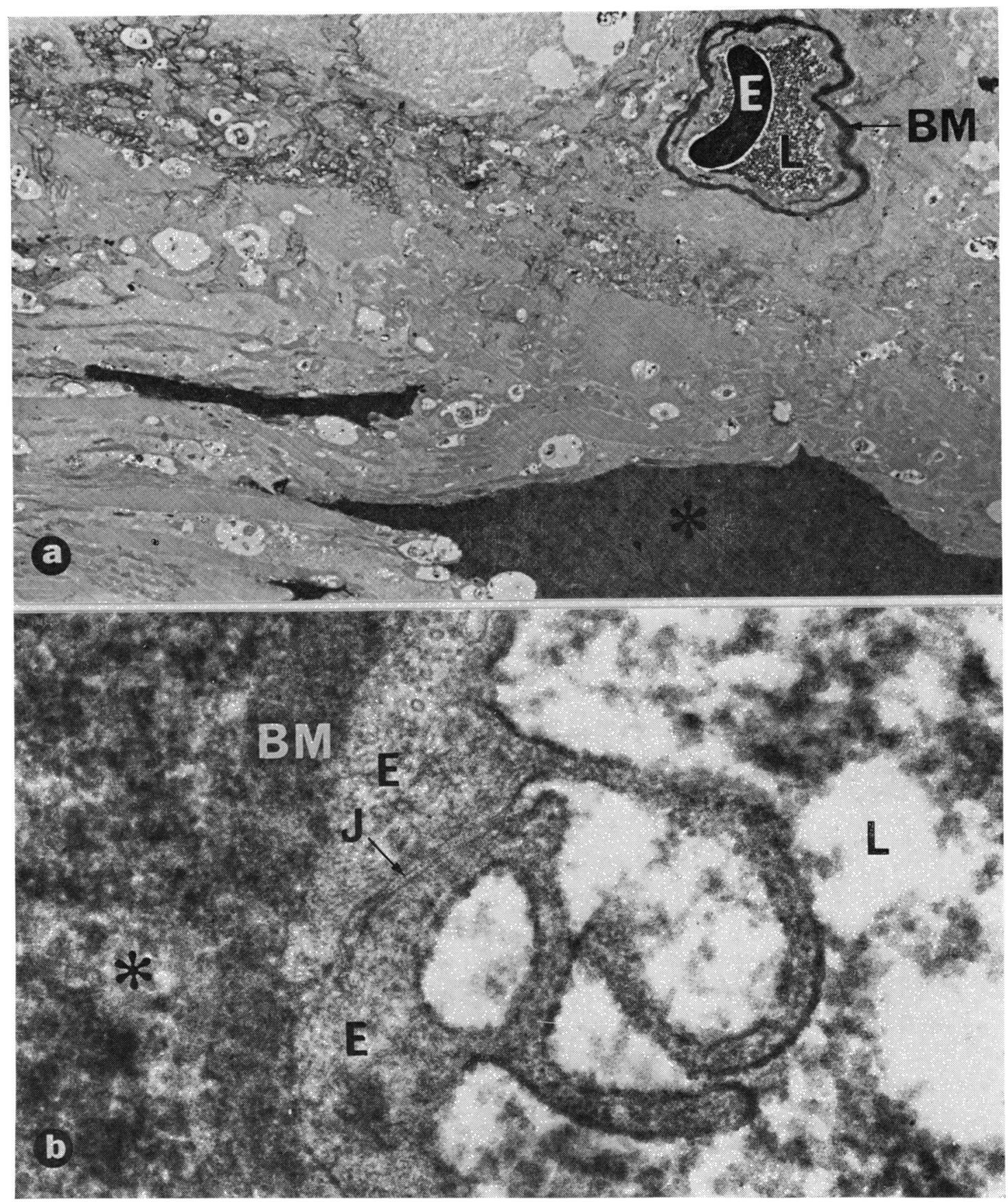

Fig. 3a Section of retina which was perfused with horseradish peroxidase at $1.5 \mathrm{~h}$ after occlusion. The dense precipitate of peroxidase reaction product is visible in the capillary lumen $(L)$ together with an erythrocyte $(E)$. Peroxidase is also present in the basement membranes $(B M)$ and there are large deposits $\left(^{*}\right)$ in the outer plexiform layer. Electron micrograph $(\times 3800)$

Fig. 3b Junction $(J)$ between 2 capillary endothelial cells $(E)$. Dense peroxidase granules are present in the capillary lumen $(L)$ and in the basement membrane $(B M)$, and there is a large extravascular accumulation of the enzyme $\left({ }^{*}\right)$, but the dense precipitate is not seen in the junction. $1.5 \mathrm{~h}$ after occlusion. Electron micrograph $(\times 84000)$ 
membrane. Numerous endothelial junctions were observed with peroxidase in the adjacent lumen and in the adjoining basement membrane, but there was no evidence that peroxidase passed through the junction (Fig. 3b).

(c) Other retinal changes (eyes 1, 2, 3, 7, 11, 13)

The most prominent early change in the nonvascular tissues of the retina was intracellular oedema. At the earliest times after occlusion the nerve fibres and mitochondria in the inner layers were swollen, and later the vacuolation was more extensive, with small areas of extracellular oedema and some pyknotic nuclei. In the most severely affected specimens the oedema could be observed macroscopically in the macular region; the inner layers were completely disorganised, and there was gross swelling with accumulations of exudate in the plexiform layers. The vacuolation was generally less marked in the nerve fibre layer close to arterioles. Conversely, pronounced vacuolation occurred in the plexiform layer adjacent to venules. The outer nuclear layer and the rods and cones always remained undamaged, and control specimens from an area of retina not drained by the occluded vein displayed markedly less vacuolation than was found in the territory of the occlusion.

\section{TO 24 HOURS AFTER OCCLUSION}

(a) Site of occlusion (eyes 15, 16)

The occluded vein retained the same appearance as at earlier times with severe oedema and haemorrhages in the adjacent retina. A small area of the nerve fibre layer in 1 specimen (No. 6) had grossly swollen axons which were filled with numerous dense bodies. In the same specimen (No. 6) a few of the larger choroidal vessels were completely filled with lysed erthrocytes, leucocytes, platelets, and fibrin.

(b) Retinal vascular changes (eyes 14, 15, 16)

These specimens showed a range of degenerative changes in the capillaries, including the slit-like lumen, vacuolation, and mitochondrial swelling. A more consistent feature of the capillaries was the presence of erythrocytes that had moved out of the capillary lumen and were lodged beneath the endothelial basement membrane (Fig. 4). Most of these intramural red cells appeared normal, but some were obviously lysed. A few white blood cells were seen migrating out from a venule, and some fibrin was also found in the walls of capillaries. Although the intramural red blood cells were outside the pericyte plasma membrane, the adjacent pericyte cytoplasm was vacuolated and the nucleus was dense and granular and appeared to be shrunken (Fig. 4). In many instances the endothelium appeared undamaged in comparison to the pericytes, and it showed no sign of the previous passage of an erythrocyte through or between the cells (Fig. 4).

Another characteristic change in some of the capillaries at later times was engorgement of the lumen with erythrocytes or, occasionally, platelets. These vessels usually had a thin, electron-dense endothelium, but the platelets were associated with more severe degenerative changes including small endothelial breaks (Fig. 5). Electron-dense plasma, fibrin, and leucocytes were often present with the platelets, and a few capillaries were found that were completely blocked with a thrombus of fibrin and plasma (Fig. 6). The endothelium and pericytes of these vessels were totally necrotic and absent in some areas, so exposing the basement membranes (Fig. 6).

Colloidal iron was visible in minute amounts in the lumen of some normal capillaries, but larger amounts of the dense precipitate were seen in capillaries filled with platelets. The tracer appeared to be trapped between the platelets and was also closely associated with fibrin. Colloidal iron was never observed in the wall of the capillary or outside the vessel.

A digest preparation of the retina with the 24 hour occlusion did not reveal any abnormality apart from some degeneration of the peripheral capillaries.

(c) Other retinal changes (eyes $14,15,16$ )

These monkeys were the first in the time series to have macroscopically visible retinal haemorrhages. At 7 hours small, diffuse, and flame-shaped haemorrhages were scattered throughout the occluded half of the retina. Sections showed that the extravascular red blood cells were almost entirely confined to the nerve fibre and ganglion cell layers. The severe oedema seen at earlier time was also present, particularly in the nerve fibre layer and in the outer plexiform layer of the macular region.

The 24-hour specimen had a large intraretinal haemorrhage which extended from the site of occlusion to the macula. The retina was swollen to 2 or 3 times its normal thickness by the large accumulation of erythrocytes in the nerve fibre and outer plexiform layers. Sections taken at the edge of the large haemorrhage revealed small numbers of erythroyctes in all retinal layers. There was also extensive oedema and some pyknotic nuclei in the outer nuclear layer.

7 TO 35 DAYS AFTER OCCLUSION

(a) Site of occlusion (eye 22)

At 7 days the occluded vein and its larger branches were filled with cell debris, platelets, and fibrin even 


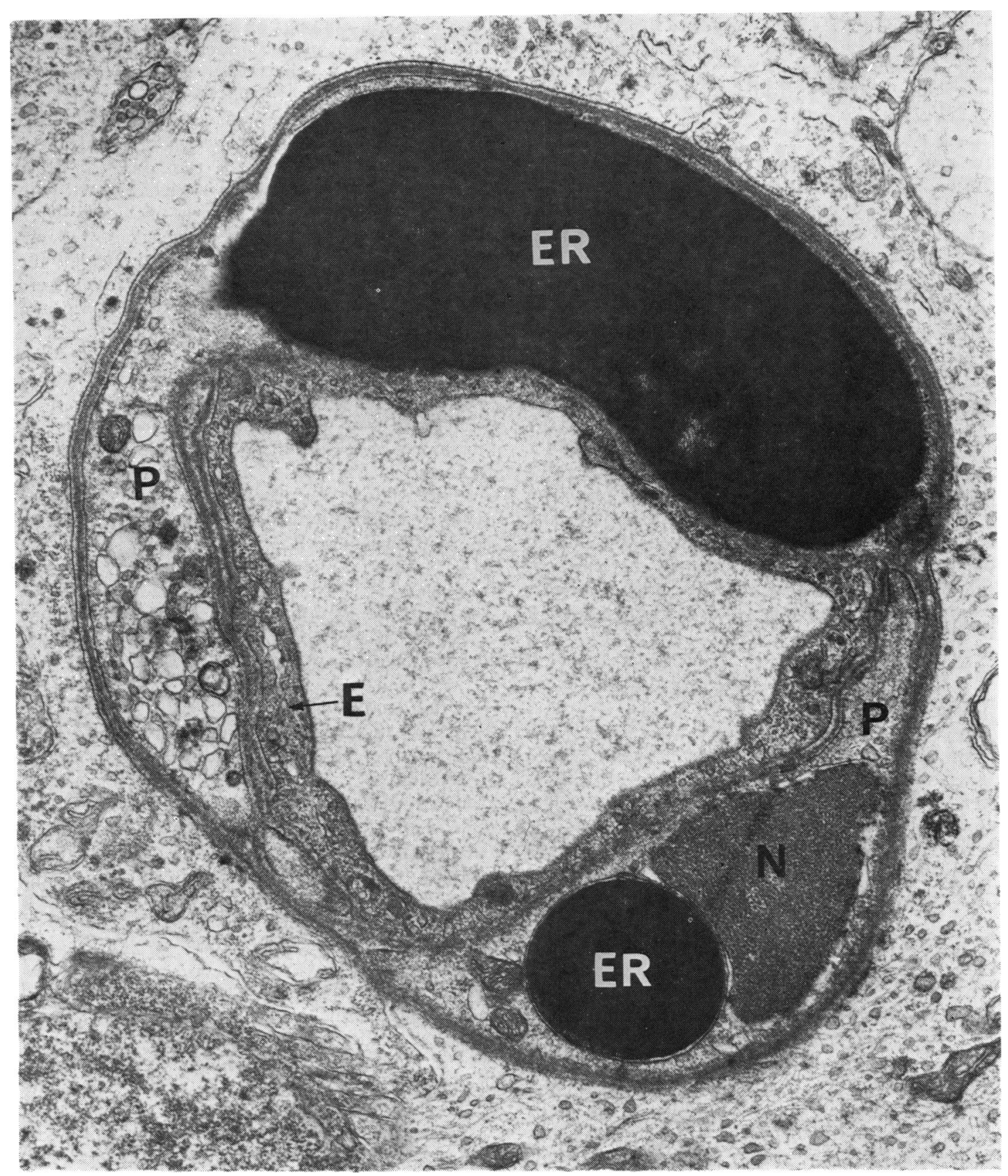

Fig. 4 Erythrocytes (ER) in the wall of a capillary. The adjacent pericyte $(P)$ is vacuolated and the pericyte nucleus $(N)$ is dense and granular. The endothelium $(E)$ appears to be undamaged. $24 \mathrm{~h}$ after occlusion. Electron micrograph $(\times 20000)$ 


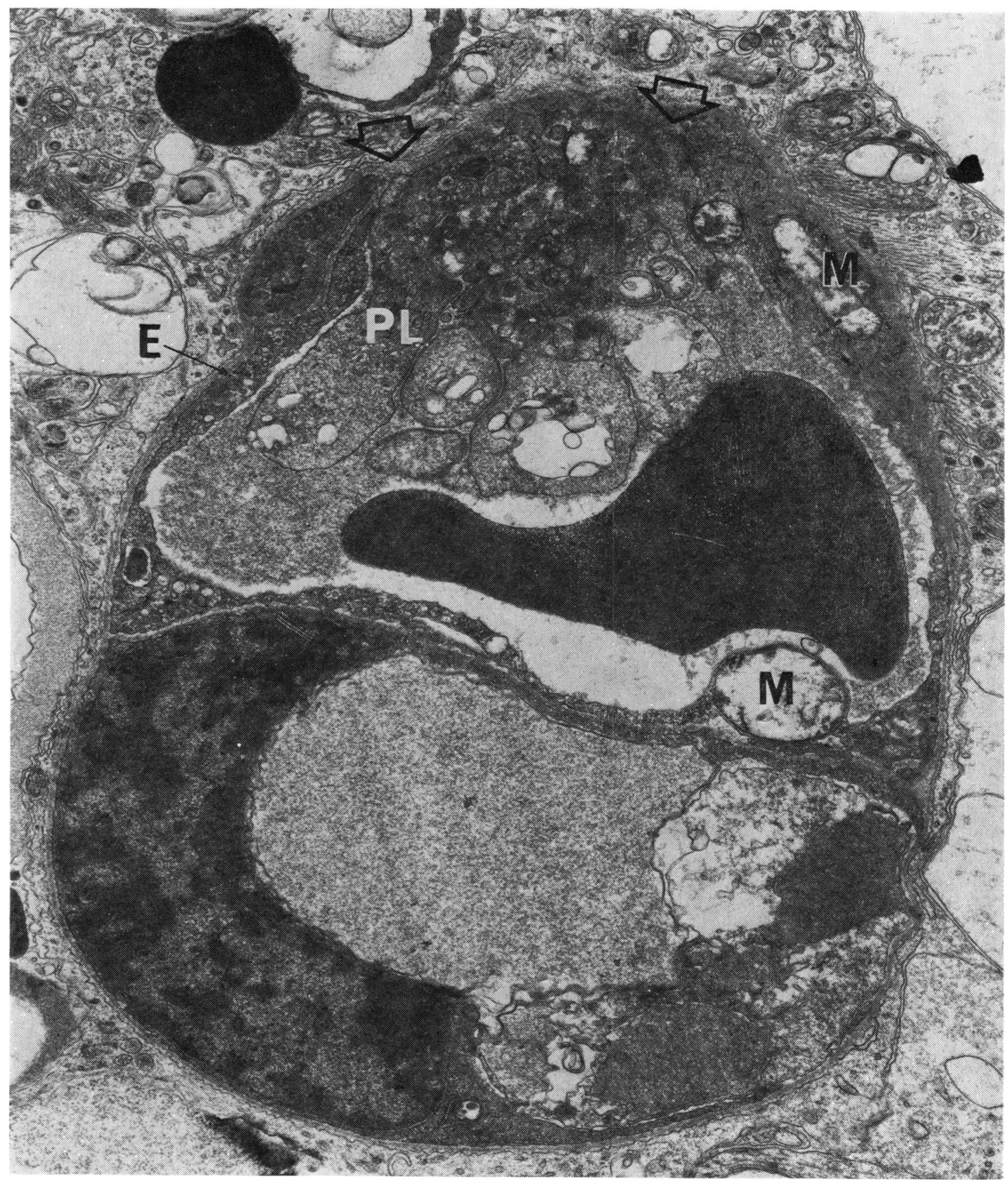

Fig. 5 Platelets $(P L)$ in a degenerate capillary at $7 \mathrm{~h}$ after occlusion. The endothelium $(E)$ is thin and electron-dense with swollen mitochondria $(M)$ and there is a break in the region indicated by broad arrows. Electron micrograph $(\times 14000)$ 


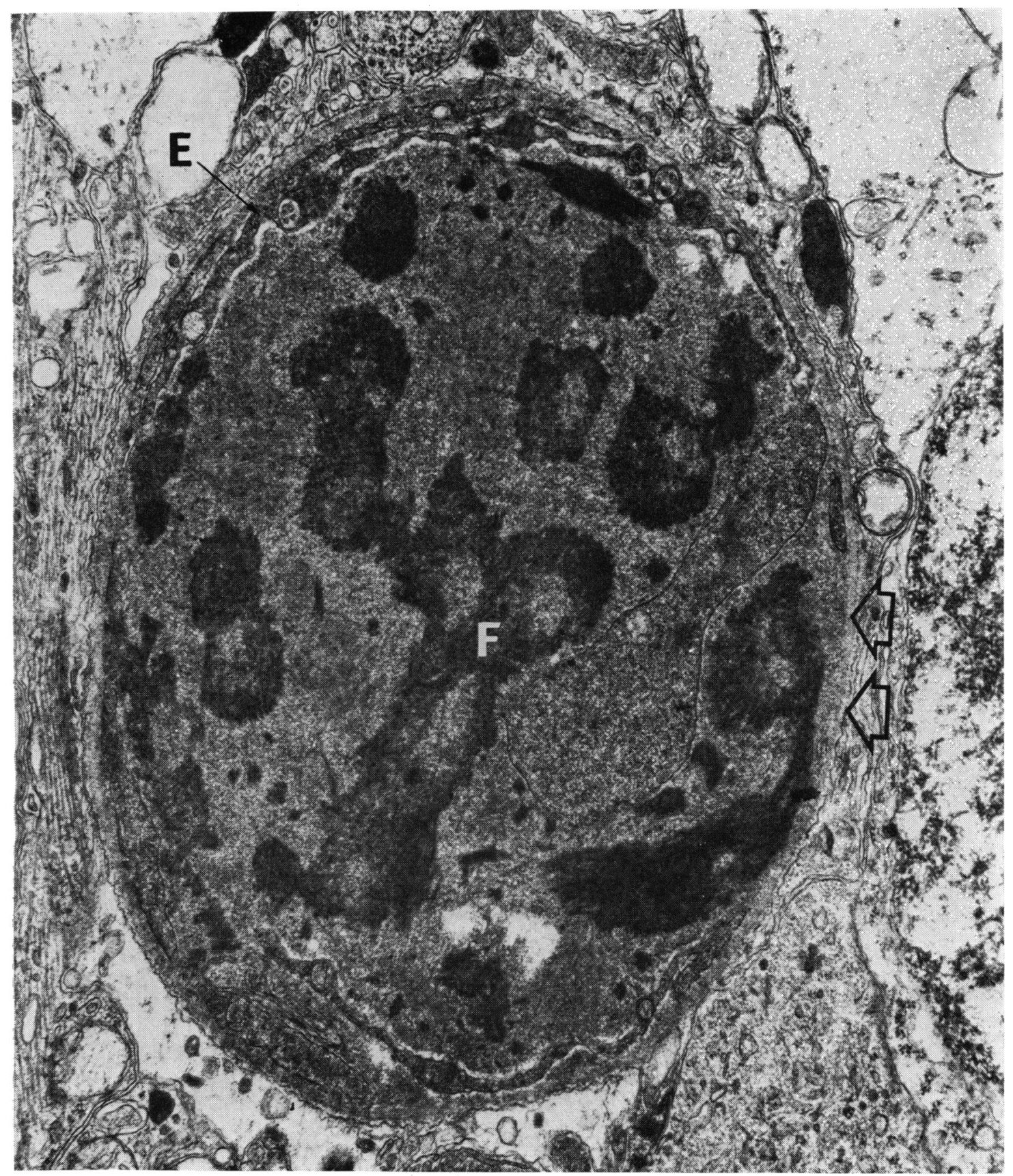

Fig. 6 Capillary totally occluded by a thrombus of fibrin $(F)$ and dense plasma. The endothelium $(E)$ is thin and absent in places (arrows). 7 h after occlusion. Electron micrograph $(\times 24000)$ 
at a distance of several millimetres from the site of occlusion. Furthermore, the endothelium and muscle cells of the corresponding artery were also slightly vacuolated. There were large intra- and subretinal haemorrhages in the region of the vein, and there was an extensive subretinal exudate with proliferation of the pigment epithelium. No marked changes were seen in the choroid; a small area of the choriocapillaries appeared to be blocked with lysed erythrocytes and cell debris but the larger vessels were all undamaged.

The actual site of occlusion was not examined at times later than 7 days. However, in the later specimens the occluded vein and its branches were highly degenerate at some distance from the site of occlusion. These abnormalities are further described under $(b)$ retinal vascular changes.

(b) Retinal vascular changes (eyes 22, 32, 33, 41) The carbon-perfused flat preparation of a retina 7 days after occlusion (No. 32) showed the greater calibre of the veins in the occluded half than in the nonoccluded half. The veins were particularly dilated and tortuous in the region temporal to the macula, and in this area there was evidence of considerable leakage from the small vessels. The capillaries in the occluded half were also more conspicuously filled with carbon than their counterparts in the superior, unaffected part of the retina. There were no areas of the retina in which the vessels did not contain carbon, and therefore the occlusion in this instance had not given rise to any large areas of capillary closure. A digest preparation of the same perfused retina did not reveal any marked changes in the capillaries, though the peripheral vessels in the occluded half contained more fragments of red blood cells and probably more eosinophilic pericyte nuclei than the vessels unaffected by occlusion.

Sections of retinae at 7 and 14 days after occlusion showed many capillaries engorged with red blood cells (Fig. 7). The erythrocytes were often fragmented or lysed, and some were located in the capillary wall (Figs. 7 and 8). The endothelium and pericytes were always degenerate and often they were virtually absent, so that the capillary wall consisted of little more than basement membranes (Fig. 7). Gaps or discontinuities in the basement membrane were only rarely seen, and usually the basement membranes appeared to restrain the enclosed erythrocytes. One break was found in the wall of a large venule or vein, and this appeared to be the origin of a large haemorrhage.

At 35 days after occlusion no normal vessels were recognised in the occluded half of the retina. The branches of the occluded vein were totally degener- ate and were represented simply by basement membranes. The adjacent artery was also necrotic; the muscle cells and endothelium were virtually absent, so that empty spaces were left between the basement membranes. The endothelium and pericytes of the capillaries were almost totally absent, so that all that remained were the basement membranes (Fig. 9). Some of these basement membrane ghosts of the capillaries were empty channels (Fig. 9), but many were invaded by processes of the Müller fibres or glial cells (Fig. 10). These cell processes surrounded any remnants of plasma or erythrocytes (Fig. 10) and occasionally filled the whole lumen. The processes entered the capillary lumen through small breaks in the basement membranes, and often the spaces formerly occupied by pericytes were also filled with invading glial cell processes. The glial cells inside the capillaries usually contained smooth endoplasmic reticulum, some ribosomes, microfilaments, and small mitochondria, all of which were typical cytoplasmic features of normal Müller fibres (Fig. 10), but in addition they sometimes contained vesicles of lipid, and occasionally the cells had the appearance of macrophages.

A digest preparation of the retina which had been occluded for 35 days confirmed the abnormal appearance of the capillaries. In the occluded half the small vessels were almost totally anucleate where vessels in the unoccluded superior half of the retina appeared normal. The division between the temporal cellular and acellular capillaries was a line corresponding to the horizontal raphe.

\section{(c) Other retinal changes (Eyes 22, 33, 41)}

At 7 days after occlusion there were extensive areas of haemorrhage in the retina. In some regions the nerve fibre layer was completely replaced by closely packed erythrocytes, and there were also some large accumulations of erythrocytes in the inner nuclear layer and outer plexiform layer. In the other layers and in other regions there were fewer erythrocytes, but they were accompanied by extensive oedema, particularly in the nerve fibre and outer plexiform layers. There was also macular oedema with detachment and loss of photoreceptors. Small areas of subretinal exudate with loss of photoreceptors were found in some other regions of the retina.

In the 14 day specimen there were regions of the retina which were severely damaged by massive intra- and subretinal haemorrhages. In at least one place the inner limiting membrane was ruptured, and erythrocytes and macrophages were present in the vitreous. Other regions of the retina, however, were relatively undamaged, oedema was not a prominent feature, but some small subretinal haemorrhages had caused a partial loss of photoreceptors. 


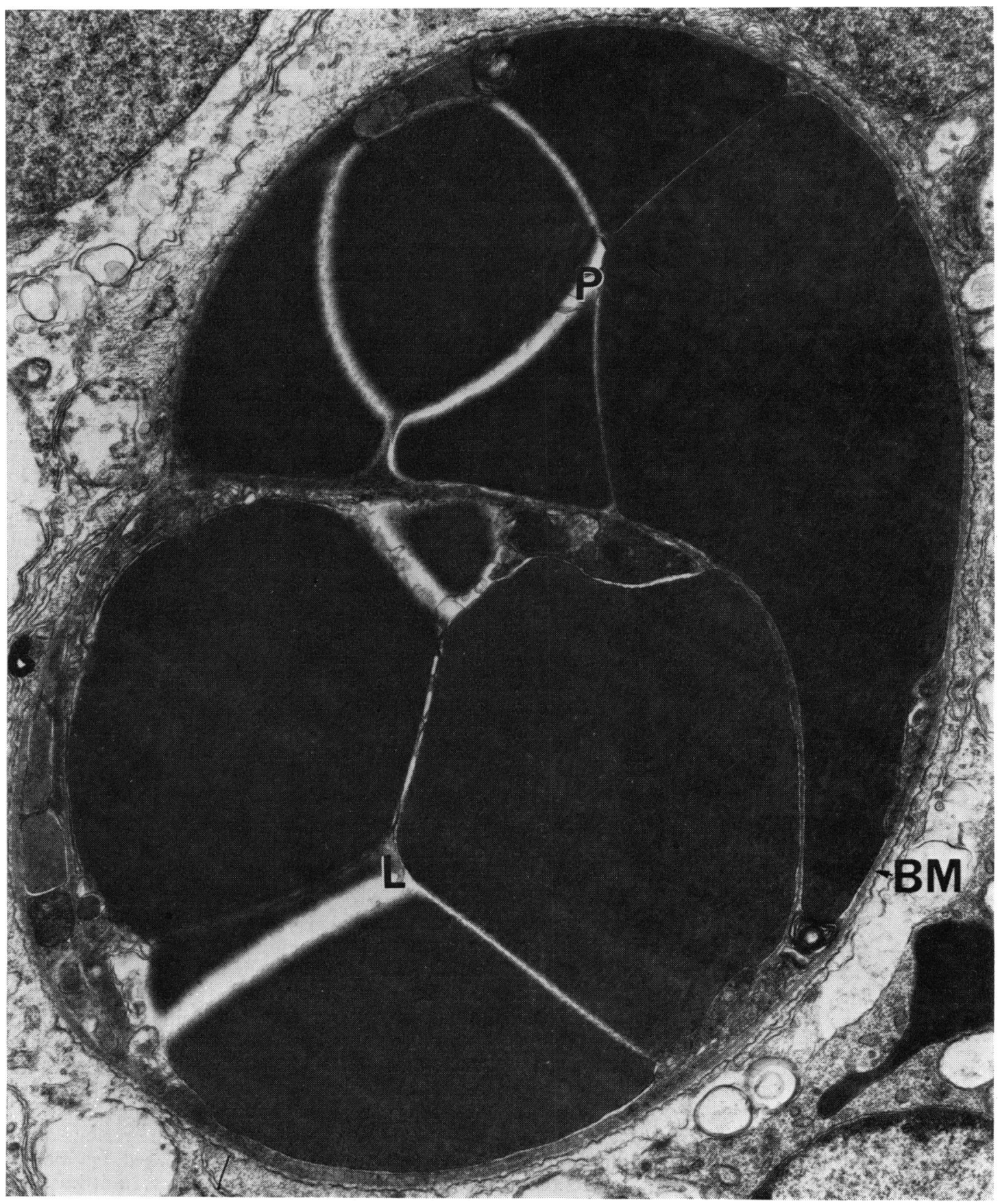

Fig. 7 Capillary engorged with erythrocytes as the result of stasis at 7 days after occlusion. The lumen $(L)$ and the pericyte lodge $(P)$ are filled with closely packed erythrocytes. The endothelium and pericytes are virtually absent and only the basement membranes $(B M)$ remain. Electron micrograph $(\times 18000)$ 


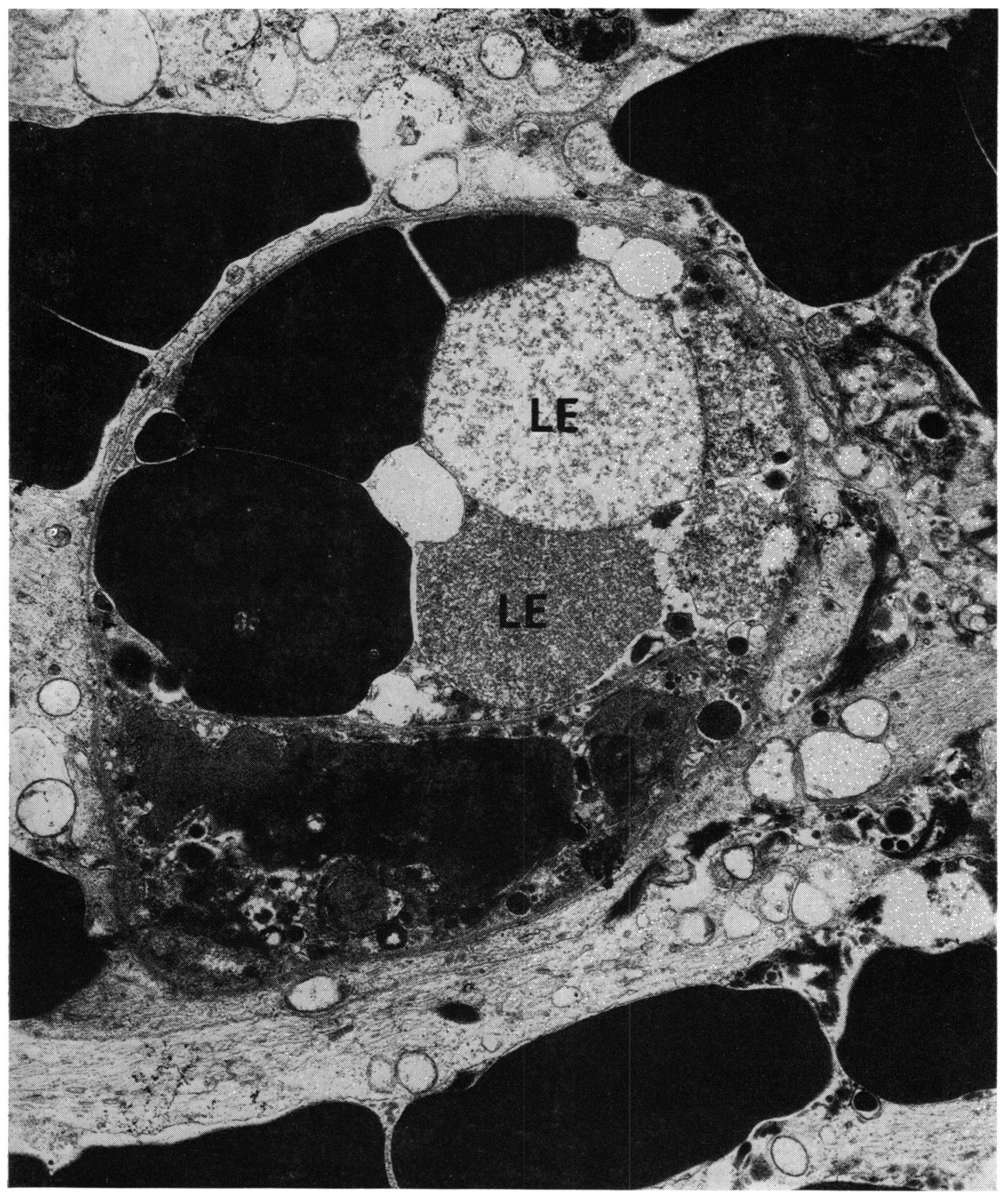

Fig. 8 Capillary in a region of haemorrhage at 7 days after occlusion. The wall of the vessel is highly degenerate and lysed erythrocytes $(L E)$ are present in the engorged lumen. Electron micrograph $(\times 10000)$ 


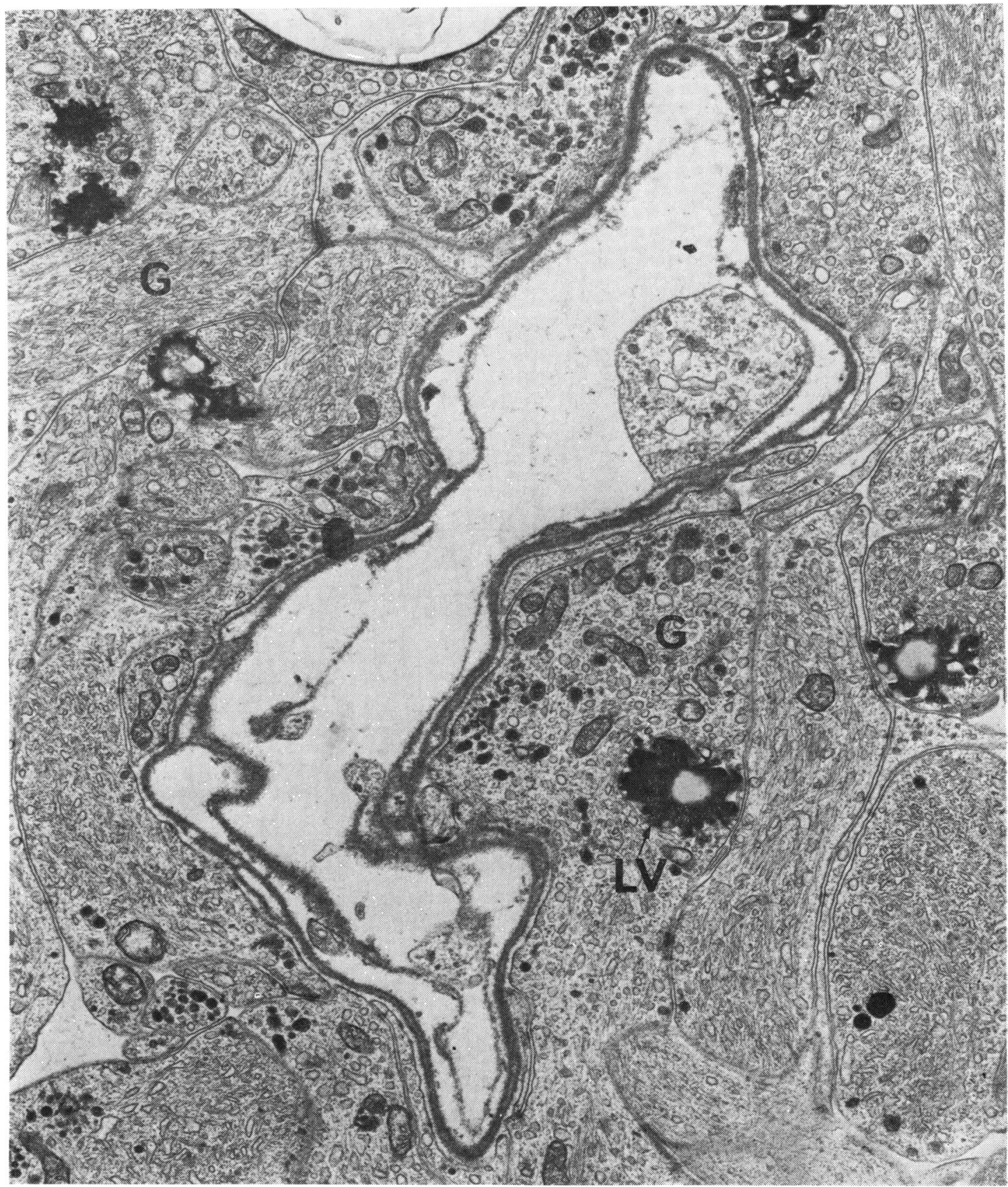

Fig. 9 Empty basement membrane ghost of a capillary at 35 days after occlusion. The vessel is surrounded by numerous glial cell processes (G) which contain vesicles of lipid (LV). Electron micrograph $(\times 14500)$ 


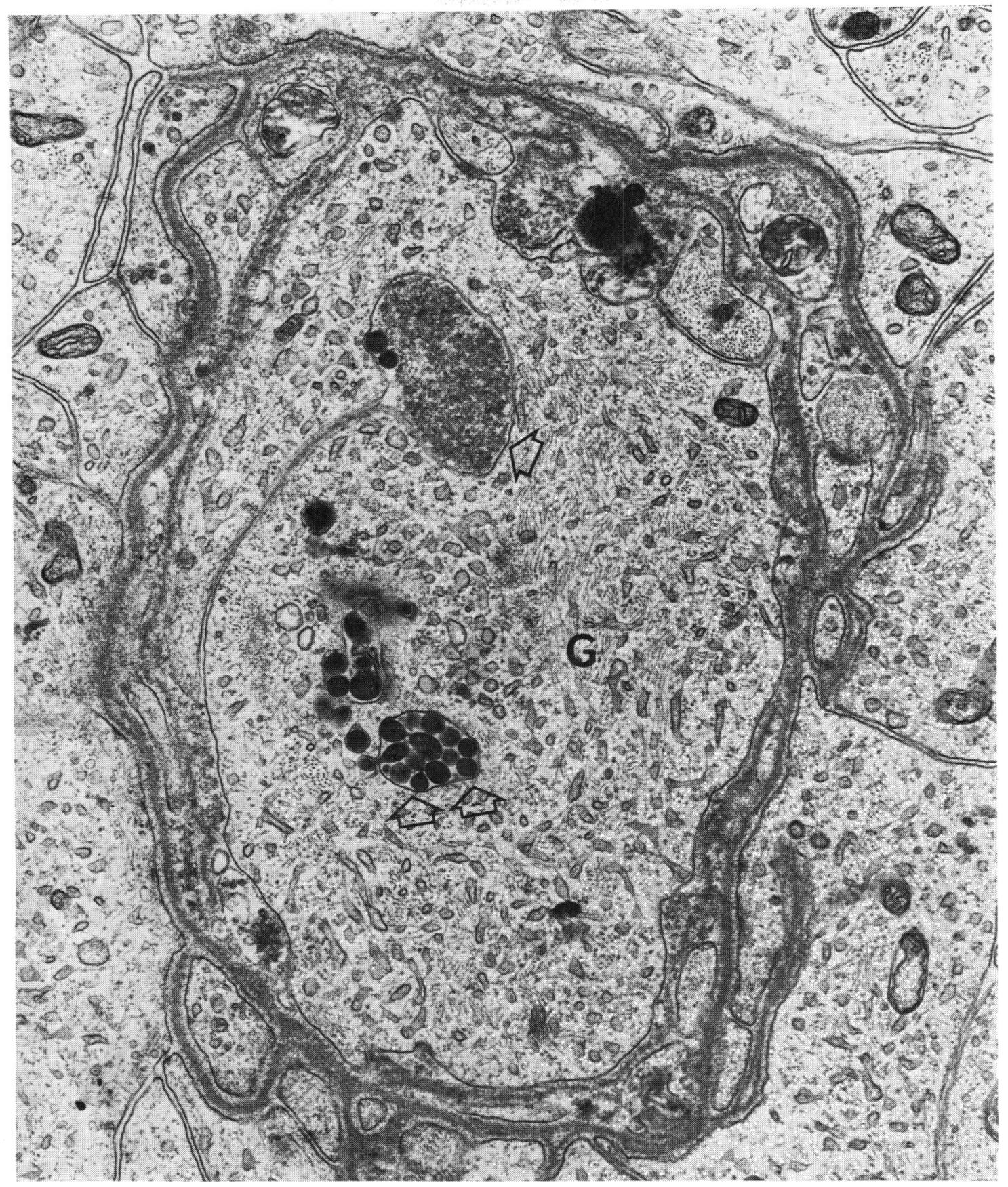

Fig. 10 Basement membrane ghost of a capillary invaded by a glial cell process $(G)$ at 35 days after occlusion. The cell surrounds a small amount of plasma (arrow) and has probably phagocytosed some dense material (double arrow). Electron micrograph $(\times 25000)$ 
The 35 day specimen again presented areas of severe retinal degeneration and areas of comparatively normal retina, although in all regions the capillaries were highly abnormal. The severely damaged areas were detached and the photoreceptors and outer nuclear layer were absent. The remaining retinal layers were usually recognisable, but in some areas there was further degeneration with the formation of cystic spaces. These regions were invaded by numerous macrophages which contained either lipid or the remains of red blood cells. In the more normal parts of the same occluded retina the photoreceptors and their nuclei appeared to be completely undamaged. The other retinal layers also were relatively normal although there were a few extravascular erythrocytes in the inner layers and the nerve fibre layer was thin and partly replaced by proliferation of glial cells.

\section{Discussion}

The histological and electron microscopical observations correlate well with the clinical and fluorescein angiographic pictures in monkeys (Hamilton et al., 1979). All the 7 to 35 day specimens (Nos. $22,32,33,41$ ) which were examined microscopically followed the path of progression with numerous haemorrhages and evidence of capillary closure. No corroborative histological studies have been made on the resolution of the disease.

Examination of the actual site of the occluding laser burn by both light and electron microscopy confirmed the occluded state of the vein. The changes detected in the choroid at the site of occlusion were mostly confined to a small area of the choriocapillaris and were probably insignificant. No damage was detected in the outer layers, and there was no loss of photoreceptors, except at the site of occlusion, until approximately 1 week after occlusion. Therefore it would seem unlikely that the changes in the retina were related to choroidal damage at the site of occlusion.

The microscopical studies have revealed a sequence of 3 major changes in the retinal microvasculature during the period from 1 hour to 5 weeks after vein occlusion. (a) Immediately after occlusion ( 1 to 6 hours) there was leakage from the capillaries in the occluded segment, and this was accompanied by retinal oedema. (b) From approximately 6 hours after occlusion there were degenerative changes in the capillaries which would account for delayed perfusion and at this time haemorrhages first appeared in the retina. (c) After about a week the capillaries were reduced to basement membrane ghosts and at the same time there was clinical evidence of capillary closure. The origins and interrelationships of these three stages of the disease will now be discussed to illustrate the probable sequence of cytological events resulting in closure and destruction of the capillaries.

\section{(a) LEAKAGE AND OEDEMA ( 1 TO 6 HOURS)}

Extravascular deposits of the perfused peroxidase were found in the retinal tissues within 1.5 hours after vein occlusion and a small number of extravascular erythrocytes were also found at the same time. The capillary endothelium and its intercellular junctions normally form an efficient blood-retinal barrier (Ashton, 1965; Ashton and Cunha-Vaz, 1965; Cunha-Vaz and Shakib, 1967), and the alterations induced by vein occlusion which permit leakage are still not fully understood.

A recent review by Ryan and Majno (1977) lists 5 possible cellular changes which may contribute to the pathogenesis of vascular leakage in inflammation. In the absence of endothelial destruction the most likely mechanism appears to be the formation of intercellular gaps by the breakdown of endothelial junctions. Opening of the intercellular junctions also allows escape of erythrocytes from the lung capillaries of guinea-pigs with experimental thrombocytopenia (Dale and Hurley, 1977).

In the present study passage of peroxidase or erythrocytes through the junctions was not seen, but neither was there any evidence of endothelial destruction until 7 hours after occlusion. We conclude, therefore, that at the earlier times leakage probably occurred via endothelial junctions which may have been temporarily disrupted. The possibility also remains that there was focal rhexis of the capillaries which was rapidly repaired and thus not detected. Furthermore, some peroxidase may have escaped from the capillaries via endothelial pinocytotic vesicles.

Tso and Shih (1976) were unable to find any morphological basis for disruption of the bloodretinal barrier in ocular hypotony even though there was leakage from the retinal vessels. Wallow and Engerman (1977), however, have demonstrated peroxidase in the endothelial junctions of retinal vessels from diabetic dogs.

Leakage in the immediate postocclusion specimens was accompanied by intracellular retinal oedema, which can be attributed to the hypoxic conditions resulting from the impaired circulation (Ashton, 1970). Extracellular oedema was initially confined to the outer plexiform layer, presumably because of the ability of this layer to absorb large quantities of fluid and because of the absence of capillaries for reabsorption (Duke-Elder and Dobree, 1967). 
(b) DEgENERATIVE CHANGES, DELAYED PERFUSION, AND HAEMORRHAGES ( 6 HOURS TO 1 WEEK)

The earliest morphological change detected in the capillaries was flattening of some of the vessels and the formation of a slit-like lumen. The flattened capillaries were usually found in the deeper layers of the retina and occasionally it appeared that they were compressed by the surrounding oedema, a process which has been described in the retina (Ashton, 1959) and in the brain (Kowada et al., 1968). Perfused peroxidase was always found in the slit-like lumens, and thus the flattened appearance of the capillaries was not associated with complete cessation of capillary perfusion, but it may have contributed to delayed perfusion. The possible role of a rise in tissue tension in causing delayed perfusion cannot be fully evaluated on static, morphological evidence alone since post-mortem compression of the vessels may have occurred. Kohner et al. (1970) found that capillaries did not reopen after absorption of retinal oedema.

Following the flattened appearance of the capillaries there were more specific degenerative changes in the endothelium and pericytes. These changes can be positively correlated with delayed perfusion, since they led to thrombus formation. The initial alteration in the cells was swelling of the mitochondria, presumably resulting from the reduced circulation and lack of oxygen. The endothelium was often less severely affected than the pericytes, possibly because of its better oxygen supply and greater distance from the toxic products of other necrotic cells in the retina (Ashton and Tripathi, 1977). There was no evidence of regeneration or proliferation of the endothelium.

A more consistent change in the capillaries at about 6 hours after occlusion was the presence of intramural erythrocytes located beneath the endothelial basement membrane and adjacent to the pericytes. Intramural erythrocytes were always associated with a degenerate appearance of the pericytes. The endothelial cells usually had a more normal appearance, and, as noted earlier, there was no evidence concerning the route of erythrocytes through the endothelium. Movement of large numbers of erythrocytes out of capillaries at 6 hours after occlusion can be correlated with the first appearance of macroscopical retinal haemorrhages at about the same time.

The continuing effects of the sluggish circulation in the later specimens appeared to result in further degenerative changes in the endothelial cells. An increased number of vacuoles appeared in the cells, the endothelium became very thin and electrondense, and eventually there were endothelial breaks.
Necrosis of the endothelium and the resulting exposure of the basement membrane resulted in the formation of platelet thrombi. Fibrin was invariably associated with the platelets and some capillaries with a necrotic endothelium were completely blocked by thrombi of electron-dense plasma and fibrin. Thus capillary degeneration resulted in areas of complete stasis in the microvasculature.

Haemorrhages first appeared in the retina at about the same time as marked capillary degeneration, and they gradually became more severe and involved more retinal layers. Although initially the haemorrhages could not be shown to be associated with rupture of the vessel wall, the massive haemorrhages at later times were clearly associated with morphological breaks in the vessels. The most severe retinal damage occurred in areas where haemorrhages were present in the outer retinal layers and subretinal region. Even after reabsorption of the subretinal blood cells the photoreceptors remained absent.

\section{(c) PERMANENT CAPILLARY CLOSURE} (1 TO 5 WEEKS)

After the first appearance of thrombi in the capillaries there was clearly stasis in the small vessels and many capillaries were filled and distended with closely packed erythrocytes. Degeneration of the endothelium and pericytes appeared to proceed rapidly in the anoxic conditions associated with stasis and there was also lysis and fragmentation of the blood cells. Eventually acellular, empty basement membrane channels were left which corresponded to the anucleate vessels seen in retinal digest preparations. The closed state of acellular capillaries has been demonstrated by Ashton (1953) and Cogan et al. (1961). Closure probably becam? irreversible after entry of proliferating glial cell prozesses into the ghost vessels. Breaks in the basement membranes which allowed entry of glial calls were seen infrequently, and the basement membranes appeared to be resistant to degenerative changes. Possibly the glial cell processes entered the vessels through the same breaks which had permitted the earlier haemorrhages.

Regeneration of the endothelium into empty basement membrane tubes could not be identified, and there was no evidence of endothelial proliferation or microaneurysm formation. The requirements for microaneurysm formation, namely, endothelial degeneration with persisting blood flow, were appearently not fulfilled in the healthy young experimental monkeys, at least within the time limits of the present observations. Intraretinal revascularisation after experimental vein occlusion has been described clinically (Hamilton et al., 1979) and by 
electron microscopy (Hamilton et al., 1975; Archer, 1976); the postocclusion time intervals, however, were usually longer than 35 days.

\section{Conclusion}

Our observations on the early stages of the progressive degeneration of capillaries and the accompanying retinal changes which followed vein occlusion can be summarised as a sequence of 7 stages (Table 2). Basically, blockage of the vein resulted in a decreased flow of blood, which produced anoxic conditions in the retina. As a result there were functional and later structural changes in the capillaries. These changes led to thrombus formation and stasis, which was followed by degeneration and finally obliteration of the microvasculature in those monkeys whose retinal circulation remained deficient.

The accompanying retinal changes were also partly explained by the histological findings. Initially there was oedema caused by stagnant flow and leakage from the small vessels. Later, more permanent retinal damage was caused by haemorrhages in the outer layers and subretinal region. Finally, after destruction of the capillaries there was atrophy of the neural elements in the inner retinal layers.

The timing of the different stages of the disease can be given only in general terms, since each monkey was an individual and not strictly part of a series. The individuality of the disease in each

Table 2 Experimental retinal vein occlusion: sequence of changes leading to permanent capillary closure

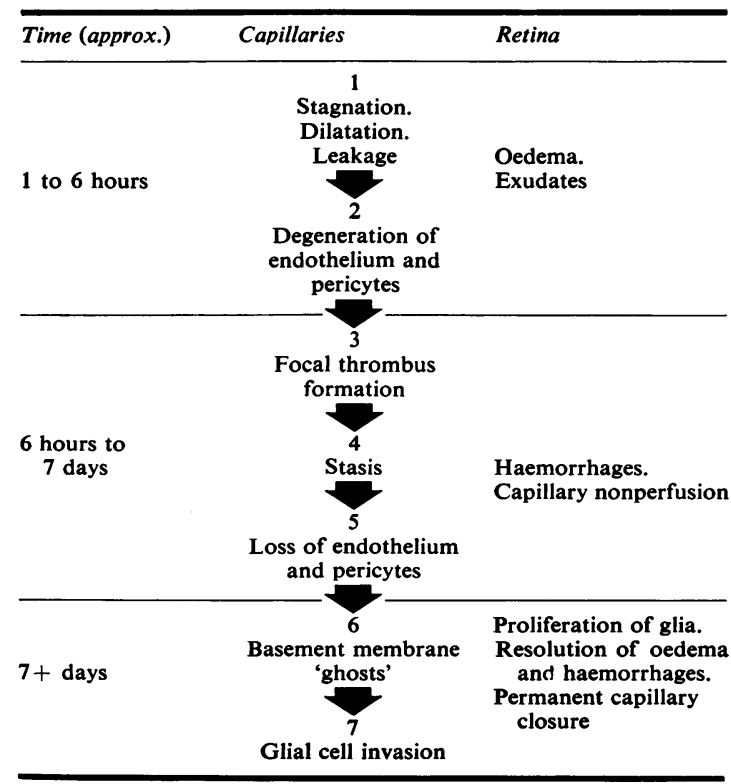

monkey was probably a result of the differing degrees of occlusion produced in each animal and the different extents to which the circulation was restored. Nevertheless, from the microscopical studies it would appear that only functional changes occurred in the first few hours following occlusion and that structural changes began to occur after about 6 hours. By 1 week after occlusion the changes in the microvasculature were probably permanent (Table 2).

It is a pleasure to thank Miss E. Robins and Mr G. Knight for the carbon perfusions and flat preparations of the retinae, Mr D. Wood for help with electron microscopy in the initial stages of this work, and Mrs A. Wood for secretarial assistance. This work was generously supported by the Wellcome Trust. Professor Ashton acknowledges the help of the Leverhulme Trust.

\section{References}

Archer, D. B., Ernest, J. T., and Maguire, C. J. F. (1976). Retinal vein occlusion. Experimental branch retinal vein obstruction. In Vision and Circulation. Proceedings of the 3rd Wm Mackenzie Memorial Symposium, Glasgow, 1974, pp. 226-242. Edited by J. S. Cant. Kimpton: London.

Ashton, N. (1953). Arteriolar involvement in diabetic retinopathy. British Journal of Ophthalmology, 37, 282-292.

Ashton, N. (1959). Diabetic retinopathy: a new approach. Lancet, 2, 625-630.

Ashton, N. (1963). Studies of the retinal capillaries in relation to diabetic and other retinopathies. British Journal of Ophthalmology, 47, 521-538.

Ashton, N. (1965). The blood retinal barrier and vascular relationships in retinal disease. Transactions of the Ophthalmological Societies of the United Kingdom, 85, 199-230.

Ashton, N. (1970). Pathophysiology of retinal cotton wool spots. British Medical Bulletin, 26, 143-150.

Ashton, N., and Cunha-Vaz, J. G. (1965). Effect of histamine on the permeability of the ocular vessels. Archives of Ophthalmology, 73, 211-223.

Ashton, N., and Tripathi, R. C. (1977). The problem of selective pericyte injury. In Proceedings of the 9 th European Conference of the Microcirculation Society, Antwerp, 1976, pp. 19-23. Karger: Basel.

Cogan, D. G., Toussaint, D., and Kuwabara, T. (1961). Retinal vascular patterns. IV. Diabetic retinopathy. Archives of Ophthalmology, 66, 366-378.

Cunha-Vaz, J. G., and Shakib, M. (1967). Ultrastructure mechanisms of breakdown of the blood-retina barrier. Journal of Pathology and Bacteriology, 93, 645-652.

Dale C., and Hurley, J. V. (1977). An electron microscope study of the mechanism of bleeding in experimental thrombocytopenia. Journal of Pathology, 121, 193.

Duke-Elder, W. S., and Dobree, J. H. (1967). Circulatory disturbances. In System of Ophthalmology, vol. X, p. 122. Edited by W. S. Duke-Elder. Kimpton: London.

Graham, R. C., and Karnovsky, M. J. (1966). The early stage of absorption of injected horseradish peroxidase in the proximal tubule of the mouse kidney: ultrastructural cytochemistry by a new technique. Journal of Histochemistry and Cystochemistry, 14, 291-302.

Hamilton, A. M., Marshall, J., Kohner, E. M., and Bowbyes, J. A. (1975). Retinal new vessel formation following experimental vein occlusion. Experimental Eye Research, 20, 493-497.

Hamilton, A. M., Kohner, E. M., Rosen, D., Bird, A. C., 
and Dollery, C. T. (1979). Experimental retinal branch vein occlusion in rhesus monkeys. I. Clinical appearances. British Journal of Ophthalmology, 63, 377-387.

Kohner, E. M., Dollery, C. T., Shakib, M., Henkind, P., Paterson, J. W., de Oliveira, L. N. F., and Bulpitt, C. J. (1970). Experimental retinal branch vein occlusion. American Journal of Ophthalmology, 69, 778-825.

Kowada, M., Ames, A., Majno, G., and Wright, R. L. (1968). Cerebral ischaemia. 1. An improved experimental method for study; cardiovascular effects and demonstration of an early vascular lesion in the rabbit. Journal of Neurosurgery, 28, 150-151.

Ryan, G. B., and Majno, G. (1977). Acute inflammation. American Journal of Pathology, 86, 185-276.

Tso, M. O. M., and Shih, C. Y. (1976). Disruption of bloodretinal barrier in ocular hypotony: preliminary report. Experimental Eye Research, 23, 209-216.

Wallow, I. H. L., and Engerman, R. L. (1977). Permeability and patency of retinal blood vessels in experimental diabetes. Investigative Ophthalmology, 16, 447-461. 